
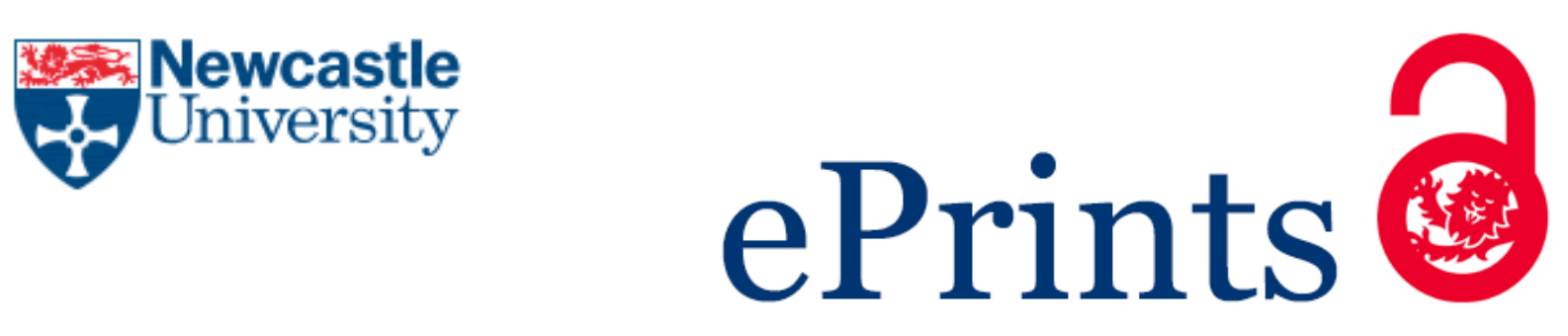

Sayers P, Walsh CL, Dawson RJ. Climate impacts on flood and coastal erosion infrastructure. Infrastructure Asset Management 2015, 2(2), 69-83.

\title{
Copyright:
}

(C) Published with permission by the ICE under the CC-BY license

(http://creativecommons.org/licenses/by/4.0/)

DOI link to article:

http://dx.doi.org/10.1680/iasma.14.00040

Date deposited:

$13 / 07 / 2015$

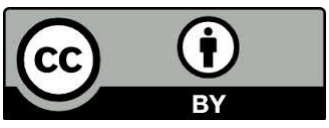

This work is licensed under a Creative Commons Attribution 4.0 International License 
Infrastructure Asset Management Volume 2 Issue 2

Climate impacts on flood and coastal erosion infrastructure

Sayers, Walsh and Dawson
Infrastructure Asset Management, 2015, 2(2), 69-83

http://dx.doi.org/10.1680/iasma.14.00040

\section{Climate impacts on flood and coastal erosion infrastructure}

1 Paul Sayers BEng CEng, MICE Partner, Sayers LLP and Fellow - Infrastructure Analytics, Environmental Change Institute, University of Oxford, UK

2 Claire Walsh BSc, PhD

Research Fellow, Centre for Earth Systems Engineering Research, School of Civil Engineering and Geosciences, Newcastle University, Newcastle upon Tyne, UK
3 Richard Dawson MEng, PhD

Professor of Earth Systems Engineering, Centre for Earth Systems Engineering Research, School of Civil Engineering and Geosciences, Newcastle University, Newcastle upon Tyne, UK
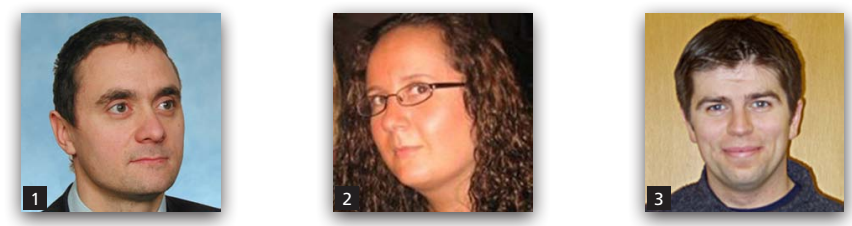

Climate change can affect the performance of flood and coastal erosion risk management infrastructure (FCERMi) through a number of mechanisms. This review highlights that while it is well known that climate change can influence the performance of FCERMi in a number of ways, there is extremely poor quantitative understanding of the physical processes of time-dependent deterioration and the impact of changing loads (and the interactions between these) on the reliability of FCERMi. If FCERMi is to be more robust to future climate uncertainties, there is an urgent need for research to better understand these interactions in the long term. This must be coupled with an updated approach to design and management that considers changes in extreme values, storm sequencing, spatial coherence, or more subtle impacts from changes in temperature, solar radiation and combinatorial affects.

\section{Introduction}

The UK government has a vision to provide 'an infrastructure network that is resilient to today's natural hazards and prepared for the future changing climate...by ensuring that an asset is located, designed, built and operated with the current and future climate in mind' (HM Government, 2011). This goal applies equally to a wide variety of infrastructure associated with flood and coastal erosion risk management (FCERMi) that act to 'control' flood waters and reduce the probability of flooding in most (if not all) of the UK floodplains that contain significant economic assets. Here we define FCERMi as any feature that is managed to reduce the chance of flooding or erosion. Table 1 illustrates the wide range of FCERMi that exists; the ontology distinguishes between local, scale infrastructure such as houses, businesses and critical service nodes, and system-scale infrastructure. For the former, example activities are presented for avoidance, resistance and recovery of assets from flood or erosion events. System-scale infrastructure is subdivided into hard path and soft path infrastructure. Hard path infrastructure refers to built assets that may be active or passive, such as embankments or floodgates. Soft path infrastructure is that making use of natural infrastructure such as the introduction of greenspaces or management of dunes and beaches.

Climate change has the potential to impact the standard of protection that FCERMi provides as well as their condition and reliability on demand. Impacts may include (Figure 1) increasing (i) the rate of material degradation (e.g. spalling of concrete, corrosion of steel, soil desiccation, surface cover erosion, etc.), (ii) the rate of wear and tear of mechanical components (e.g. through increased 'on-demand' use), or (iii) the severity of loads, including increased wave overtopping and flow velocities leading to episodic erosion and damage to structural elements (e.g. removal of rock armouring, toe scour, loss of surface cover). Reliability of FCERMi may reduce in response to these changes, and new designs and management approaches (with enhanced maintenance budgets) may be needed.

FCERMi providers are starting to establish a better understanding of these impacts and how to reflect the severe uncertainties associated with climate change within infrastructure investment plans (e.g. Tarrant and Sayers, 2012). For many infrastructure providers, however, climate change continues to be dealt with in a rather rudimentary fashion within the infrastructure design process (largely through the consideration of precautionary allowances applied to basic descriptions of climate loads). Little consideration is given to changes in extreme values, storm sequencing and spatial coherence or the more subtle impacts of temperature, solar radiation or events occurring in combination.

This paper focuses on the impact of climate change, that is, changes in rainfall, groundwater levels, coastal storms, extreme temperatures and invasions/biological attacks on the performance of a range of FCERMi. Furthermore, the paper highlights the challenges that 
Local-scale infrastructure

Private homes

and businesses

Avoidance

Resistance

Recovery

Critical service

Avoidance

nodes

Resistance

Recovery
Raising properties above flood levels (actively, floating homes, or passively, raised thresholds) or some other way to avoid flooding. The use of flood products and construction detailing to prevent water entering a property.

Use of building materials and practice such that, although flood water may enter the building, no permanent damage is caused, structural integrity is maintained and drying, cleaning and minor repairs are facilitated.

Raising critical functions/building above flood levels. Deployment of property scale 'ring dykes'.

The use of flood products and construction detailing to prevent water entering a property.

The use of function-specific building designs and network redundancy to avoid loss of function if flooded (i.e. continued power or communication distribution).

System-scale infrastructure

Hard path infrastructure - Planning, design and management of built infrastructure

Linear and

network assets

Active

$$
\begin{aligned}
& \text { Passive - Above } \\
& \text { ground } \\
& \text { Passive - Below } \\
& \text { ground }
\end{aligned}
$$

Point assets

Active

Passive

Soft path infrastructure - Using natural infrastructure systems

$\begin{array}{cc}\text { Watercourse } & \text { Channel } \\ \text { Coast } & \text { Floodplain } \\ & \text { Foreshore and } \\ \text { backshore }\end{array}$

Urban landscape $\quad$ Urban land use

Rural catchment Rural land use
Barriers that can be deployed as temporary and demountable defences.

Raised defences and shore parallel structures (i.e. embankments, levee or dyke, breakwaters) through to storm water storage ponds. Individual pipes, CSOs and the drainage network they compose.

Pumps, floodgates and sluices.

Fixed trash screen, groynes, as well as interface assets (that link above and below ground linear systems) such as manholes and gullies.

The management of vegetation (e.g. weed cutting) and sediment (e.g. shoal removal and dredging).

The management of floodplain roughness and debris recruitment. The management of dunes and beaches through active (e.g. recycling and profiling) and passive (e.g. sand fencing, marram grass planting) management as well as natural wetlands and soft cliffs. The engineering of urban green space, managing surface permeability (e.g. through sustainable urban drainage systems) and debris recruitment.

The management of rural run-off, sediment yields as and debris recruitment.

Note: FCERMi includes any feature that is actively managed to reduce the chance of flooding or erosion (Sayers et al., 2010). Dams and associated ancillary structures are excluded from this paper.

Table 1. An ontology of flood and coastal erosion infrastructure assets

infrastructure designers and planners face in delivering climate change-ready infrastructure, as well as highlighting opportunities that could contribute to a transformation towards adaptive infrastructure. The paper concludes by identifying remaining research, appraisal and practice challenges for FCERMi.

\section{Sensitivity of FCERMi to climate change}

The performance of FCERMi is often represented using a fragility function derived from structural reliability analysis (Dawson and Hall, 2006; Sayers et al., 2012a; van Gelder et al., 2008). Such analysis typically provides a 'snapshot' of performance given 
Infrastructure Asset Management

Volume 2 Issue 2
Climate impacts on flood and coastal

erosion infrastructure

Sayers, Walsh and Dawson

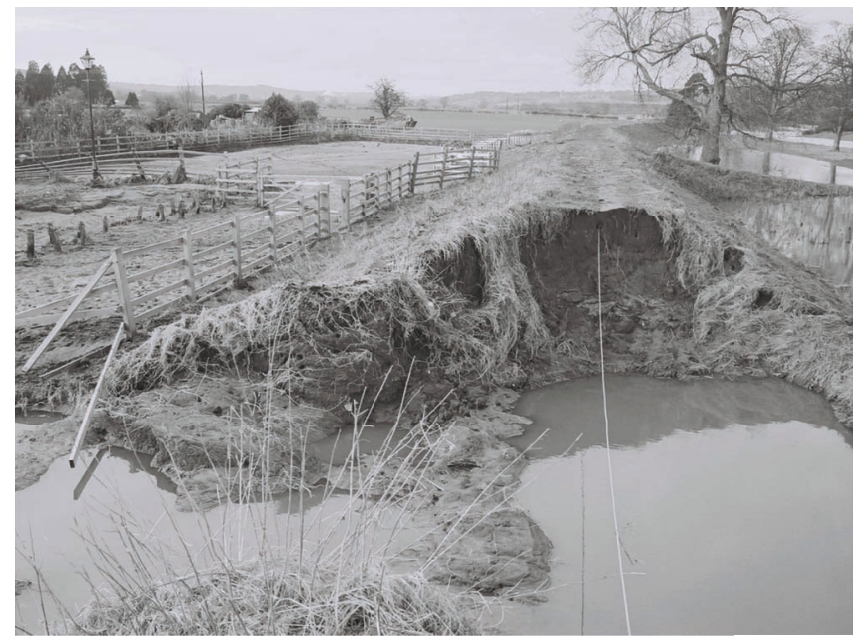

Flood defence embankment breaches following high water levels at Corbridge in Northumberland (courtesy of Mike Walkden, 10 January 2005).

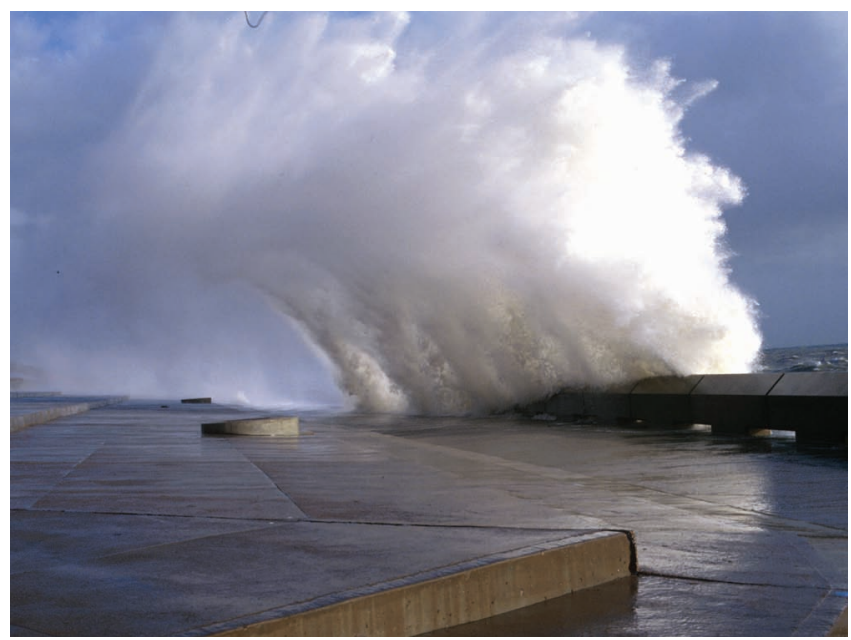

Overtopping of the seawall at Samphire Hoe (picture courtesy of the WhiteCliffs

Country Project, taken October 1996)

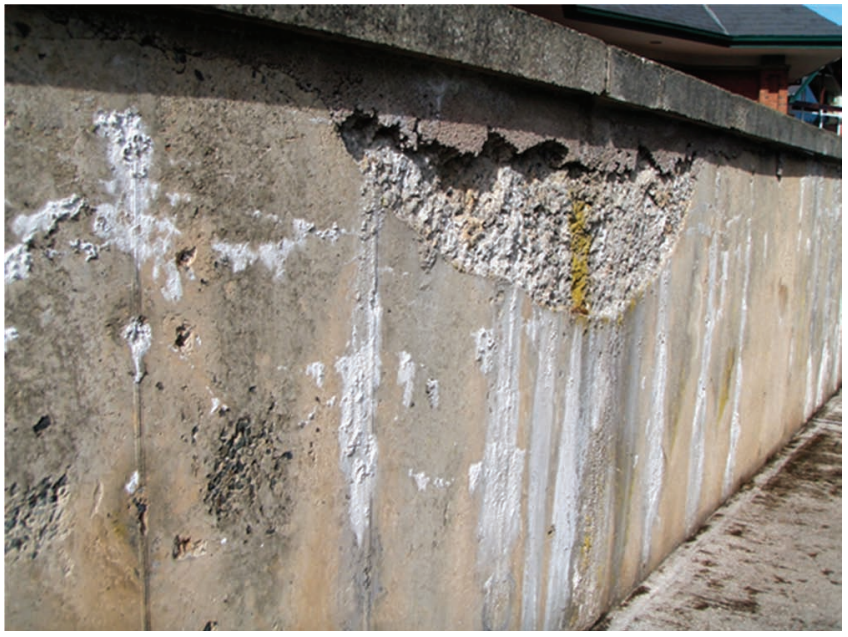

Spalling of concrete cover layer (courtesy of the Environment Agency).

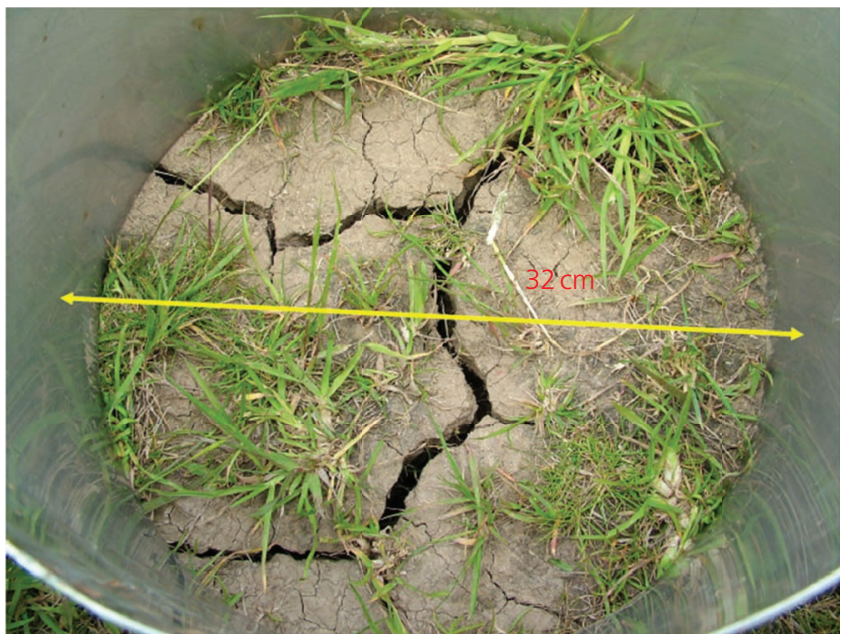

Desiccation of the earth embankment (courtesy of Prof. Mark Dyer)

Figure 1. Examples of infrastructure failure and failure modes

particular material properties, failure modes and loading conditions. Although the evidence on time-dependent deterioration processes remains extremely limited (e.g. Buijs et al., 2009; Environment Agency, 2013), it is widely accepted, with a high degree of confidence, that the performance of FCERMi will be sensitive to climate change (Table 2), a conclusion supported by observation (Box 1).

\section{Changes in rainfall and the impact on urban drainage infrastructure}

Wilby (2012) concludes that 'pluvial studies generally report greater increases to multi-day precipitation totals, and proportionately greater changes to extreme single-day events'. As urban drainage systems (piped and surface storage services) and pumped catchments have a fixed capacity to accommodate pluvial events, any increase in the severity of rainfall events and run-off will bring into question the ability of these systems to cope. Changes to the duration, sequence and spatial extent of rainfall (including towards less intense long-duration rainfall) will also influence antecedent conditions, run-off and the moisture content of structures and green spaces and hence the design performance of the drainage network (Dunne and Black, 1970). In both cases, the higher rates of surface run-off may increase debris recruitment (leaves, wood and anthropogenic debris) and subsequent transport and blockage of surface drains (Streftaris et al., 2012).

Changes in rainfall and the impact on river infrastructure Understanding the changes in the variability of the climate (e.g. the potential for extreme storms) is perhaps more important to river 


\begin{tabular}{|c|c|c|c|c|c|}
\hline \multirow{2}{*}{$\begin{array}{l}\text { Primary source } \\
\text { of flooding } \\
\text { managed }\end{array}$} & \multirow{2}{*}{$\begin{array}{c}\text { Example } \\
\text { infrastructure }\end{array}$} & \multicolumn{2}{|c|}{ Primary climate change sensitivity } & \multicolumn{2}{|c|}{ Impact on FCERMi performance } \\
\hline & & Change & Confidence & Scale of impact and examples & Confidence \\
\hline \multirow{3}{*}{ Pluvial } & \multirow{3}{*}{$\begin{array}{l}\text { Urban drainage } \\
\text { networks (surface } \\
\text { and sub-surface) }\end{array}$} & Severity of individual storms & Low & \multirow{3}{*}{$\begin{array}{l}\text { Moderate } \\
\text { Heightened run-off; } \\
\text { increased flood flows }\end{array}$} & \multirow[t]{3}{*}{ High } \\
\hline & & Spatial coherence & Low & & \\
\hline & & Temporal sequence (Wilby, 2012) & Low & & \\
\hline \multirow[t]{3}{*}{ Fluvial } & \multirow[t]{3}{*}{$\begin{array}{l}\text { River embankments, } \\
\text { culverts, barriers } \\
\text { and pumps }\end{array}$} & $\begin{array}{l}\text { Severity of individual storms (high } \\
\text { flows, low flows) (Cardoso and Bettess, } \\
\text { 1999; Schmocker and Hager, 2013; } \\
\text { Sentenac et al., 2013; Sturm et al., } \\
\text { 2011; Wallerstein and Arthur, 2013) }\end{array}$ & High & \multirow[t]{3}{*}{$\begin{array}{l}\text { High } \\
\text { Crest overflow, bypassing; } \\
\text { accelerated deterioration; } \\
\text { reduced maintenance } \\
\text { window; increased chance } \\
\text { of failure }\end{array}$} & \multirow[t]{3}{*}{ High } \\
\hline & & Spatial coherence (Kilsby et al., 2007) & Low & & \\
\hline & & $\begin{array}{l}\text { Temporal sequence (Chun et al., 2013; } \\
\text { Whal et al., 2013) }\end{array}$ & Low & & \\
\hline Groundwater & $\begin{array}{l}\text { Cliff slopes, } \\
\text { foundations of } \\
\text { raised structures, } \\
\text { coastal wetlands }\end{array}$ & $\begin{array}{l}\text { Mean and extreme values (higher and } \\
\text { lower levels) (Foster, 2001; Hiscock et } \\
\text { al., 2011; Iverson and Major, 1986; } \\
\text { Loveless et al., 1996; Macdonald et } \\
\text { al., 2012; Schweckendiek et al.., 2014; } \\
\text { Wols and van Thienen, 2014) }\end{array}$ & Moderate & $\begin{array}{c}\text { Low-moderate } \\
\text { Soil instabilities (slope failure); } \\
\text { differential settlement } \\
\text { (instability); greater/less } \\
\text { saline intrusion }\end{array}$ & Moderate \\
\hline \multirow[t]{6}{*}{$\begin{array}{l}\text { Coastal and } \\
\text { estuarine }\end{array}$} & \multirow{6}{*}{$\begin{array}{l}\text { Hard and soft } \\
\text { shoreline structures } \\
\text { (seawalls, beaches } \\
\text { to wetlands), tidal } \\
\text { barriers }\end{array}$} & $\begin{array}{l}\text { Higher mean sea levels (and associated } \\
\text { increase in incident wave energy) } \\
\text { (Horsburgh and Lowe, 2010) }\end{array}$ & High & \multirow{6}{*}{$\begin{array}{l}\text { Very high } \\
\text { Increased chance of failure } \\
\text { due to, for example, increased } \\
\text { overtopping; scour; beach } \\
\text { lowering; coastal squeeze }\end{array}$} & \multirow[t]{6}{*}{ High } \\
\hline & & $\begin{array}{l}\text { Severity of individual storm } \\
\text { (surges, waves) (Hemer et al., 2013; } \\
\text { Woolf and Wolf, 2010) }\end{array}$ & Moderate & & \\
\hline & & $\begin{array}{l}\text { Increased storminess (severity, } \\
\text { frequency, sequence) (Karunarathna } \\
\text { et al., 2014) }\end{array}$ & Low & & \\
\hline & & Wave direction (mean) & Low & & \\
\hline & & Salinity (Holliday et al., 2010) & Low & & \\
\hline & & Acidity (Turley et al., 2010) & Low & & \\
\hline $\begin{array}{l}\text { Temperature, } \\
\text { solar radiation } \\
\text { and drought }\end{array}$ & $\begin{array}{l}\text { Earth embankments } \\
\text { and other 'soil' and } \\
\text { 'vegetation'-based } \\
\text { infrastructure }\end{array}$ & $\begin{array}{l}\text { Extremes of temperature (cold, hot, } \\
\text { extreme dry periods) (Blenkinsopp } \\
\text { and Fowler, 2007; Burke et al., 2010; } \\
\text { Karoly and Scott, 2006; Murphy et al., } \\
\text { 2009; Rahiz and New, 2013; Tham et } \\
\text { al., 2011; Vidal and Wade, 2009) }\end{array}$ & High & $\begin{array}{c}\text { Moderate } \\
\text { Accelerated desiccation of } \\
\text { soils; freeze-thaw induced } \\
\text { spalling; loss of strengthen } \\
\text { in surface cover; loss } \\
\text { of vegetation for green } \\
\text { infrastructure; surface drying; } \\
\text { increased cliff erosion }\end{array}$ & High \\
\hline $\begin{array}{l}\text { Problematic } \\
\text { invasions and } \\
\text { bacterial attacks }\end{array}$ & $\begin{array}{l}\text { Potential to affect } \\
\text { both hard and soft } \\
\text { infrastructure in } \\
\text { fluvial, coastal and } \\
\text { estuarine settings }\end{array}$ & $\begin{array}{l}\text { Changes in the prevalence and nature } \\
\text { of microbes and invasive species } \\
\text { (CIRIA, 2005; Defra, 2013; Melchers, } \\
\text { 2014; Stewart et al., 2011) }\end{array}$ & Moderate & $\begin{array}{c}\text { Moderate } \\
\text { Unwanted species (e.g. } \\
\text { mosquitos around standing } \\
\text { water/sustainable urban } \\
\text { drainage systems); Japanese } \\
\text { knot-weed reducing channel } \\
\text { conveyance; increased cases } \\
\text { of accelerated low water } \\
\text { corrosion in estuaries }\end{array}$ & Low \\
\hline
\end{tabular}

Table 2. Summary of primary load exposures and examples of infrastructure that may be influenced by such exposures in terms of change in climate sensitivity and confidence in understanding this change; and impact on FCERMi performance and confidence in understanding such change 
The winter of 2013/14 was one of, if not the, wettest on record. Preliminary analysis by the Met Office and the Centre for Ecology and Hydrology (CEH) concluded that although no individual storm was exceptional, the clustering and persistence of the storms was unusual (Met Office and CEH, 2014). The majority of river defences were shown to be capable of protecting urban conurbations from the cumulative effects of a series of significant, though not extreme, rainfall events. However, many were damaged by the succession of storms and the progressive damage caused by exposure to persistently high flow velocities and discharges.

At the coast, severe gales and long, high-energy ocean waves caused significant damage to coastal infrastructure. For example, on December 4-5, 2013, a major North Sea storm surge coincided with one of the highest tides of the year. The threat to the east coast was similar to that of 1953; however, improved coastal defences and warning systems avoided major damage.

In late December and early January, successive deep cyclonic systems led to rainfall that triggered flash flooding, particularly in southwest England. For example, discharge in the Thames at Kingston remained above $275 \mathrm{~m}^{3} / \mathrm{s}$ for longer than in any previous flood episode. In January 2014, the Thames Barrier was raised 13 consecutive times as high fluvial flows and high spring tides coincided (Met Office and CEH, 2014). The succession of events saturated the ground, leading to extensive and protracted flooding and the associated disruption of transport, agriculture, which cut off some towns in the Somerset Levels (Met Office and CEH, 2014).

Box 1. The winter of 2013/14 highlighted the performance of FCERMi as highly sensitivity to loading conditions outside of those considered during design

infrastructure than changes in mean flows. This is because changes in the morphology of the catchment is most responsive to individual storm events and any associated increased erosion (including scour around bridges, embankments, bends, etc.) or accretion (leading to loss of channel section or blockage) can undermine the performance of FCERMi. Persistently saturated soils also act to decrease the stability of embankments, and issues were highlighted as a concern during the winter of 2013/14. These issues are discussed in more detail below.

\section{More frequent higher river flows and water levels}

More frequent, higher flows that scour the toe of an embankment or bridge can critically undermine the stability of the structure and lead to collapse (Cardoso and Bettess, 1999; Sturm et al., 2011). High river flows can also recruit and transport debris leading to blockage of point assets such as culvert entrances and bridges (Schmocker and Hager, 2013; Wallerstein and Arthur, 2013). More frequent higher in-river water levels, both above and below the crest level of the embankment, can also increase the chance of collapse.

Without sufficient downtime to maintain mechanical and electrical assets (e.g., major pumps, barriers), their on-demand reliability is likely to decrease as higher flows and tidal levels become more frequent (Atkins, 2006). This is likely to be a key consideration for both smaller and large active structures, including the Thames Barrier (Harvey et al., 2012).

\section{More frequent lower river flows}

More frequent, lower river flows are not typically associated with catastrophic failures. When coupled with warmer temperatures, however, they may lead to drying out of embankments and accelerated weathering-related deterioration (Sentenac et al., 2013).
More extreme low flows have the potential to have a more dramatic impact, including altering the function of the river ecosystem and its ability to regulate flood flows (Newson and Large, 2006).

\section{Storm sequences and clusters}

The nature and sequencing of individual storm events in each cluster are important determinants of the associated impact on FCERMi and hence flood risk (Kilsby et al., 2007). Similarly, the frequency and duration of intermittent dry periods also impact flood defence infrastructure. Changes in the intermittency and clustering of extreme events are anticipated by some climate studies (Chun et al., 2013; Whal et al., 2013). The recent flood events of 2013/14 have highlighted that there is little doubt that when they do occur, clustered events have a real impact on FCERMi. These events also highlight knowledge gaps in our understanding of the resistance of grass-covered slopes and beach systems to repeat exposure to storms, as well as the reliability of repeated on-demand operations of piping. The winter floods have also highlighted that some of the most important uncertainties lie in our understanding of the existing climate (especially in the area of storm sequencing) even before forward projections of climate change are made. These sequences may well be critical and may require re-evaluation of the statistical loading paradigm under which infrastructure is currently designed and appraised.

\section{Increased persistence}

Prolonged/more intense precipitation can increase soil moisture levels within earth embankments, leading to reduced soil suction (on which the stability of many over steepened embankments rely), increasing pore pressures and increasing the likelihood of mass instability (Glendinning et al., 2009). 


\section{Changes in groundwater and impacts on related infrastructure}

Despite few infrastructure having the sole purpose of managing groundwater floods, groundwater flows are an important consideration in understanding the performance of raised defences. For example, higher than design groundwater flows can (i) bypass a raised defence and flood the land behind (Macdonald et al., 2012), (ii) exacerbate scour (Loveless et al., 1996), (iii) drive progressive erosion and piping of the embankment or foundation soils (Schweckendiek et al., 2014), and (iv) destabilize soil slopes and cliffs, increasing the chance of a catastrophic slip (Iverson and Major, 1986). In urban areas, recent discussions have also focused on the relationship between increased groundwater levels and ingress in to piped drainage systems by means of below-ground pathways (but limited evidence exists).

During extended periods of lower-than-average rainfall, low groundwater levels can lead to differential settlement and resulting instability (Wols and van Thienen, 2014), with significant impacts on urban infrastructure, including FCERMi assets (Foster, 2001). Lower groundwater levels at the coast can also lead to saline intrusion, exacerbating the corrosion of engineered infrastructure and reducing the natural infrastructure capital of coastal freshwater water and brackish lagoons (Hiscock et al., 2011).

Although the interaction between groundwater and climate processes is poorly understood (Taylor et al., 2013). There is a general consensus that groundwater levels tend to be slow to respond to driving rainfall conditions. Any changes in the temporal sequencing and spatial coherence of rainfall events are therefore likely to be important.

Changes in coastal storms (wave and sea levels) and the impact on coastal and estuarine infrastructure

Infrastructure at the coast has perhaps the greatest sensitivity to climate change of all FCERMi. Sea level rise (the strongest of climate change signals) acts to reduce the depth-limiting effect of near-shore waves (Sutherland and Woolf, 2002; UKMMAS, 2010). In turn, this leads to increased overtopping and the potential for larger wave impact forces (and subsequent structural damage and increased breach potential). Larger waves (or more persistent storms) are also likely to drive coastal morphology change and, particularly where backshores are constrained, lower beach level, further exacerbating the impact of sea level rise. Over the medium to long term, any growth in offshore wave heights is therefore likely to be expressed at the coast (Hall et al., 2006). These issues are discussed in more detail below.

\section{Mean sea level}

The majority of the UK's sea defence structures are exposed to depth-limited wave conditions. In the absence of sea level rise, this implies that nearshore wave heights will stay the same despite a change in offshore wave conditions (Burgess and Townend, 2004). Unconstrained beaches are naturally resilient to progressive slow change, evolving naturally in response to storms and variations in mean sea levels, wave climate and currents. Significant lengths of coast, however, are constrained by engineered sea defence structures (46\% of England's coastline; $28 \%$ in Wales; $20 \%$ in Northern Ireland and 7\% in Scotland; UKMMAS, 2010). Many of these structures fix the location of the backshore and prevent natural onshore migration. As a result, beaches and wetlands can be trapped in a 'coastal squeeze' between rising sea levels and the fixed shoreline. In response, beaches lower and water depths increase. The depthlimitation further reduces, exposing the beach to larger waves with consequential further lowering (Ranasinghe et al., 2012).

Increases in sea level rise and beach lowering have many knock-on impacts. In addition to undermining the backshore structures and increasing the chance of collapse, many UK sea defence schemes are designed to specific standards of safety that set overtopping limits to ensure the safety of promenade users and/or the structural stability of the crest and backshore cover (Environment Agency, 2008). Overtopping rates are very sensitive to small changes in mean sea level, and small changes in sea level are likely to cause a significant increase in the number of defences that 'fail' to provide the required standard of protection (Environment Agency, 2008). Although tipping points are site specific (e.g. Hall et al., 2015; Hinkel et al., 2013), when they are exceeded, this may drive the need to move from one form of infrastructure to another. For example, the ability of a beach and dune systems to adapt to sea level rise may be limited by the availability of space to retreat and the supply of sediment (Dawson et al., 2009; Walkden and Hall, 2005). As a result, at some point, alternative systems of defence may be needed. Other possible influences include loss of saltmarsh buffers; saline intrusion; beach lowering and liquefaction (Sutherland et al., 2007); tidal locking of drained catchments as well as the creation of some opportunities, for example, to create wetlands.

A quantified exploration of the potential impacts of climate change for a limited number of pilot sites was, however, presented in the Defra commissioned study in Coastal Defence Vulnerability 2075 (CDV2075) (Sutherland and Gouldby, 2003; Sutherland and Wolf, 2002). This study considered a range of climate drivers and highlighted increased overtopping (sea level rise of $0.35 \mathrm{~m}$ will cause average increases in overtopping volume of between $50 \%$ and $150 \%$, depending on structure type, location and modelling approach), increased scour potential (scour and structural damage potential may increase by $16 \%$ for the vertical seawall and less than $2 \%$ for the sloping embankments, and shingle beaches, however, will depend on how the partial standing wave velocities at a specific coastal structure change), and accelerated coastal steepening (if the observed coastal steepening continues in response to sea level rise, overtopping rates will increase by a further $15 \%$, approximately; Soulsby et al., 1999). Although each stretch of coastline will respond differently, CDV2075 concluded that the standard of protection provided by coastal structures was most sensitive to sea level rise. Dawson et al. (2009) demonstrated that long-term changes in flood and erosion risk in North Norfolk were also significantly more sensitive to sea level rise than changes in growth of offshore wave heights and changes in direction. 
More direct evidence of impact of sea level rise on FCERMi is starting to emerge. For example, the closure frequency of the Thames Barrier has increased over the past 30 years (19831989: 4; 1990-1999: 35; 2000-2009: 75; 2010-March 2014: 65; Environment Agency, 2014). Although these figures should be interpreted with care (as the operating rules governing closures and maintenance regimes have changed over time), analysis of the drivers of individual closures by Lavery and Donovan (2005) suggests the underlying frequency of surge-related closures has increased in line with sea level rise.

\section{Wave climate and joint waves and surge}

The incident wave angle, height and period and the coincident tidal conditions all influence impact pressures, overtopping rates (Pullen et al., 2007) and sediment transport rates both longshore and crossshore (Chini et al., 2011). Evidence for change in wave angle is limited, and any offshore changes are likely to be mitigated by natural processes of refraction. Toe scour is typically more responsive to incident wave height and period alone, both of which are highly sensitive to changes that relax the depth-limiting effect, including increases in mean sea level and surge heights (Environment Agency, 2012).

\section{Storm sequencing}

Beaches undergo continuous and ongoing morphodynamic changes as a result of waves, tides and wind at a range of time scales. Significant erosion, however, is typically episodic and takes place in response to a combination of the wave conditions, water levels, groundwater as well as geology and presence or absence of structures (local or remote to the site). Impacts of individual storms and the impact of clusters of storms, where storms occur at close succession, are both extensively discussed by others (e.g. Karunarathna et al., 2014). Future change in storm sequence is therefore widely recognised as having the potential to significantly influence the performance of coastal FCERMi.

\section{Extreme temperatures and dry periods}

Concrete structures, like other infrastructure, are likely to deteriorate faster if they experience more frequent and extreme periods of freeze-thaw (Auld et al., 2007; Environment Agency, 2013). Prolonged hot dry periods are likely to accelerate desiccation of surface soils on earth embankments (Figure 1). Extreme hot and cold temperatures can act to restrict or even stop mechanical and electrical assets from operating (Rowan et al., 2013; Sayers and Dawson, 2014).

Increasing working with natural processes to help manage flood risk (in a way that protects, restores and emulates the natural regulating function of catchments, rivers, floodplains and coasts) is being recognised as a legitimate and important component of FCERMi (Demuzere et al., 2014; POST, 2011). Central to the idea is working with the river and coastal processes (and flooding) rather than against them. 'Soft path' infrastructure (e.g. green roofs, wetland storage, shelter belts, urban ponds, floodplain reconnection) and 'hard path' infrastructure measures (e.g. bypass channels, controlled storage) are both important aspects of modern flood management and, in many cases, if managed well, offer some degree of natural resilience to change. This does not mean their performance will be unchanged by climate change. High temperatures and drought can, for example, influence the performance of 'soft path' measures, significantly reducing the ability for infiltration, altering the mix of the vegetation and/or encouraging the formation of standing water and associated undesirable outcomes such as disease or increased mosquito population (Armitage et al., 2012).

\section{Problematic invasions and biological attacks}

Although often overlooked, the vegetation, microbes and nutrients present within marine and freshwater systems are important components of the FCERMi system. Vegetation within watercourses needs to be managed to maintain conveyance and avoid blockage; marine vegetation can provide important buffers against erosion at the coast, and nutrients and microbes can attack concrete and steel structures (Gu et al., 2011). For example, accelerated low water corrosion (ALWC, the attack of concrete and steel structures by nutrients and microbes in the marine and estuarial environment) is an important influence on the performance of flood defence structures (Melchers, 2014). Infrastructure in tidal and brackish water, such as the Thames Estuary, are particular susceptible to ALWC and can experience rates of corrosion exceeding $1 \mathrm{~mm} / \mathrm{side} /$ year (CIRIA, 2005), a rate that is expected to increase with higher temperatures (Stewart et al., 2011).

Conveyance of river channels, afflux at structures and the stability of flood defences can also be influenced by invasive species such as Japanese Knotweed (Defra, 2013). The preferential growth and survival of such species can be influenced by their adaptation to conditions of high temperatures or drought. Internationally, climate change has been associated with the potential increase in more aggressive, non-native, animal burrowers that undermine the stability of flood defences, although there is currently no evidence to suggest this is occurring in the UK.

\section{Challenges and opportunities for the adaptation of FCERMi}

The objective of adaptation is to ensure that infrastructure is able to continue to offer acceptable performance in the face of potential increases in extreme weather events, such as storms, floods and high temperatures. Decisions made today must therefore consider how the performance needs may change and build in flexibility so that infrastructure systems can be modified without incurring excessive, or unnecessary, cost. Given that replacement costs of England's FCERMi are estimated to be £24bn (NAO, 2014), the most significant adaptation is likely to come through changes in maintenance operations, improving collaboration with emergency managers, recognising emergency management as an integral function of managing infrastructure. New designs and strategies, however, provide the opportunity to build infrastructure that is innovative and future ready, which might include using the inherent adaptability of natural infrastructure, greater precaution in critical 
locations, a focus on shorter design lives with planned adaptation, or transformational design approaches that provide multiple benefits and functions (Figure 2).

Recent analysis (Environment Agency, 2014) concludes that 'it is quite conceivable that the level of investment needed to address it [climate change] could be double that at present'. This is supported by the Foresight Future Flooding Study (Evans et al., 2004a, 2004b), which highlights the continued importance of engineered infrastructure to all four scenarios considered, with maintenance costs needing to rise by $£ 6 \cdot 25-25 \mathrm{~m} /$ year over the 21 st century. During the Thames Estuary 2100 study, a wide range of climate futures and flood management responses were explored, and a flexible strategy was developed where future expenditure was based upon observed sea level rise with little immediate investment required to purchase that flexibility (Reeder and Ranger, 2011; Tarrant and Sayers, 2012). Innovation in the way existing infrastructure is modified, and new infrastructure designed is now

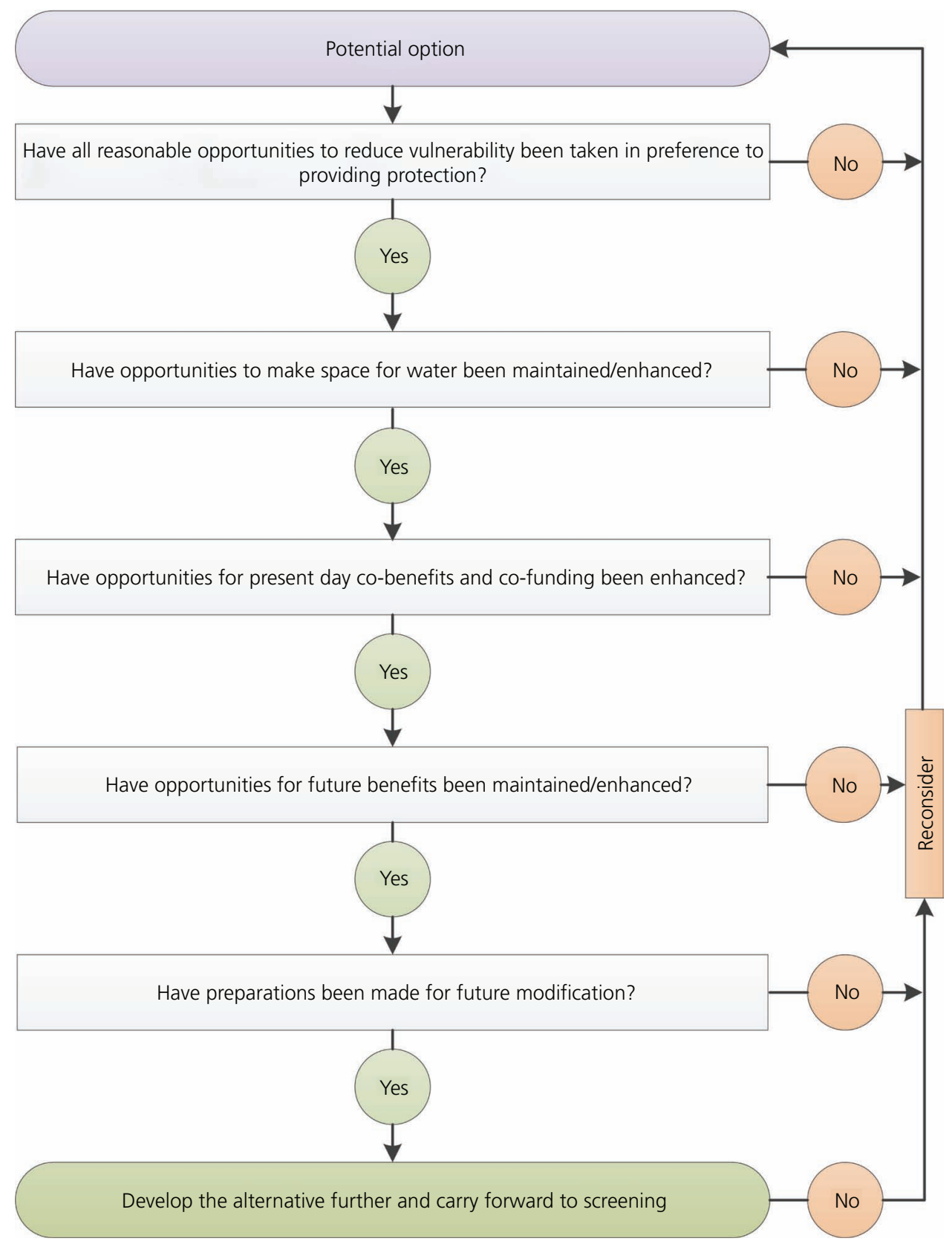

Figure 2. Key considerations in promoting an adaptive approach to infrastructure choices 
Infrastructure Asset Management

Volume 2 Issue 2
Climate impacts on flood and coastal

erosion infrastructure

Sayers, Walsh and Dawson needed. Some of the challenges and opportunities in delivering this necessary innovation are discussed below.

\section{Modifying existing infrastructure}

Retrofitting or modifying infrastructure at a range of scales will be an important feature of future modifications. The Adaptation Sub-Committee (ASC) (2011a) noted that 'buildings are a priority area for adaptation, because decisions concerning the design, construction and renovation of buildings are long lasting and may be costly to reverse'. Over longer timeframes, it is realistic to retrofit at the landscape scale, not just upsizing traditional urban drainage systems but transforming the built and rural environments to be more water sensitive. This might include a range of measures that mimic or enhance natural processes, including permeable paving, green infrastructure, small-scale storage ponds, and using urban features such as streets and parks as temporary flood pathways. Individually, these measures may offer limited benefits, but given sufficient change over long periods, their cumulative benefits should become clear.

\section{Designing new hard engineered structures with future change in mind}

Various simple examples of adaptable design exist, for example, purchasing land in the lee of an embankment to facilitate future raising or widening, or designing foundations that anticipate a heightened embankment in the future (see Figure 3). Such options often demand greater upfront expenditure than perhaps would be the case if future change had been ignored; there are seldom, true win-win situations. Flexible solutions are, however, likely to be more cost-effective over the longer term. For example, beach nourishment is often promoted as a flexible solution in that the amount of fill placed on the beach can be modified from one nourishment campaign to the next, in the light of improving understanding of beach behaviour and changing objectives with respect to risk reduction.

There is, of course, a close connection between flexibility and robustness. Flexible solutions tend to be robust to uncertainty as they are able to be adapted to perform well under a wide range of possible conditions, assuming that future adaptation decisions are taken in a timely way. Existing FCERMi appraisal guidance (Environment Agency, 2014) is in line with the Treasury Green Book (HM Treasury, 2011) and does include some advice about accounting for future climatic change and uncertainty. Decision makers and planners have been slow to take up these approaches; therefore, practical methods for decision tree analysis and the application of real options analysis have started to emerge (e.g. Woodward et al., 2013). Despite this, there remain few examples where FCERMi has been purposefully designed to facilitate future modification in response to observed changes in climate, and significant engineering innovation will be required to make a real transformation in infrastructure provision.

\section{Recognising the concept of a design storm is dead}

Typically, FCERMi will be designed to protect against a single 'design storm' (which may be described in terms of storm surge level, high flow rate, or rainfall duration and intensity). The 2007 floods in the UK highlighted that a single spatially coherent event could affect large parts of the country simultaneously with severe knock-on impacts for supply chains and critical service provision (Pitt, 2007). The 2013/14 winter floods further exposed inadequacies in this existing approach, highlighting the fundamental difference between a 'single event' and a prolonged sequence of events upon an increasingly saturated land and progressively weakened FCERMi (as witnessed in the collapse of the main railway line in Dawlish in 2014).

Uncertainties about future climate are factored in by addition of a precautionary allowance onto the design-loading conditions (Environment Agency, Undated). For example, moving gate weirs (such as radial and buck gate weirs) are normally designed so that the underside of the gate(s) can be raised above an anticipated peak water level. Changes in spatial coherence and temporal sequencing of storms events, although widely recognised as important, are not a standard consideration in design. Appropriate infrastructure choices, and design details, will only start to emerge as the full richness and potential impacts of climate change are recognised. This will include recognising that the single design storm is 'dead'.

\section{Understanding wider societal impacts of floods and infrastructure failure}

Local authorities face difficult trade-offs when planning future development. The cost to the local economy of constraining development in areas at risk from flooding or erosion (now or in the future) can be significant. Often, either opposing demands to develop brownfield sites or the lack of alternative sites mean there is little choice. However, planning for the long term is crucial. FCERMi is often a central feature in Catchment Flood Management Plans, Shoreline Management Plans and Strategies, but it is unclear if these studies are sufficiently innovative and sufficiently influential to modify local authority development plans. ASC (2011a) noted that despite there being evidence of longterm, strategic planning for adaptation (e.g. Shoreline Management Plans), it was unclear how influential these initiatives were on local development plan policies and actual development decisions. They also found limited evidence that local authorities were factoring in long-term costs when making decisions on the strategic location of new development in their Local Plan. Local authorities should take a strategic approach to managing vulnerability at the scale of communities as well as at the property level. This will require explicitly weighing up the long-term costs of climate impacts against social and economic benefits from development that are more immediately released.

FCERMi is not constructed for its own intrinsic value but to provide wider benefits to society through the protection it provides and the functions it supports. As such, FCERMi is inextricably linked with ecosystem services (Sayers et al., 2015), the provision of critical infrastructure and associated services (e.g. ICT, energy, health). The impact of a failure within FCERMi can extend far beyond the 


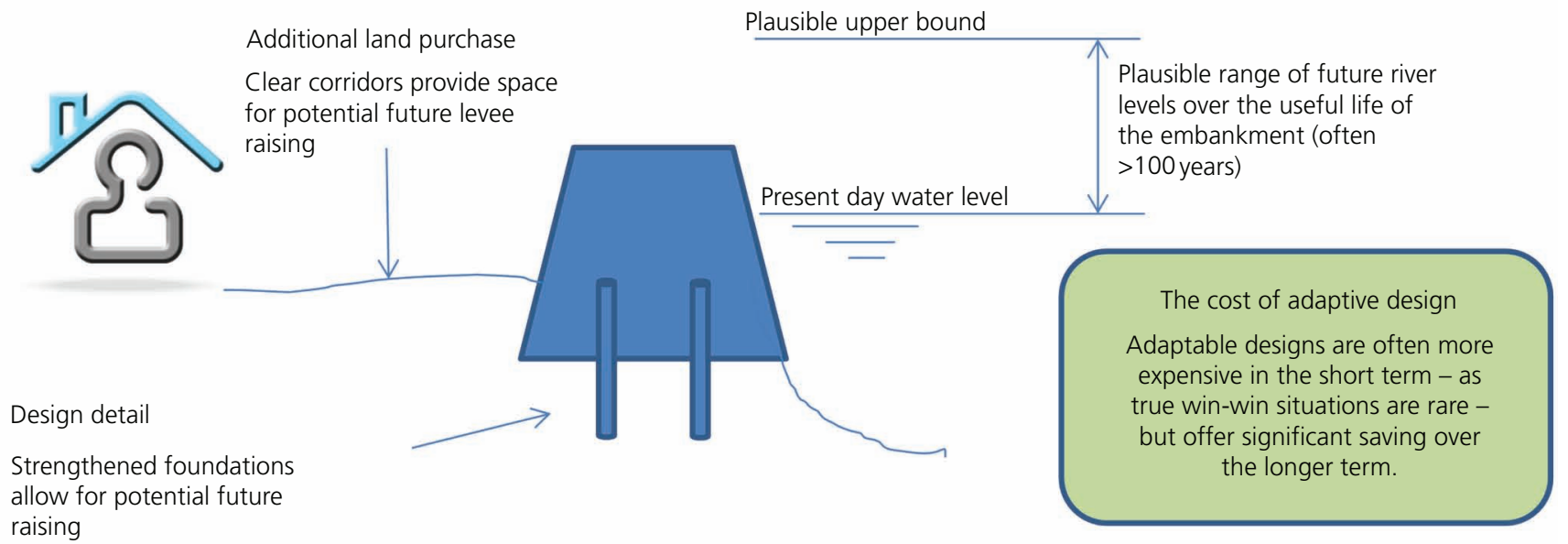

The cost of adaptation - Good designs keep future options open without incurring unnecessary additional expenditure

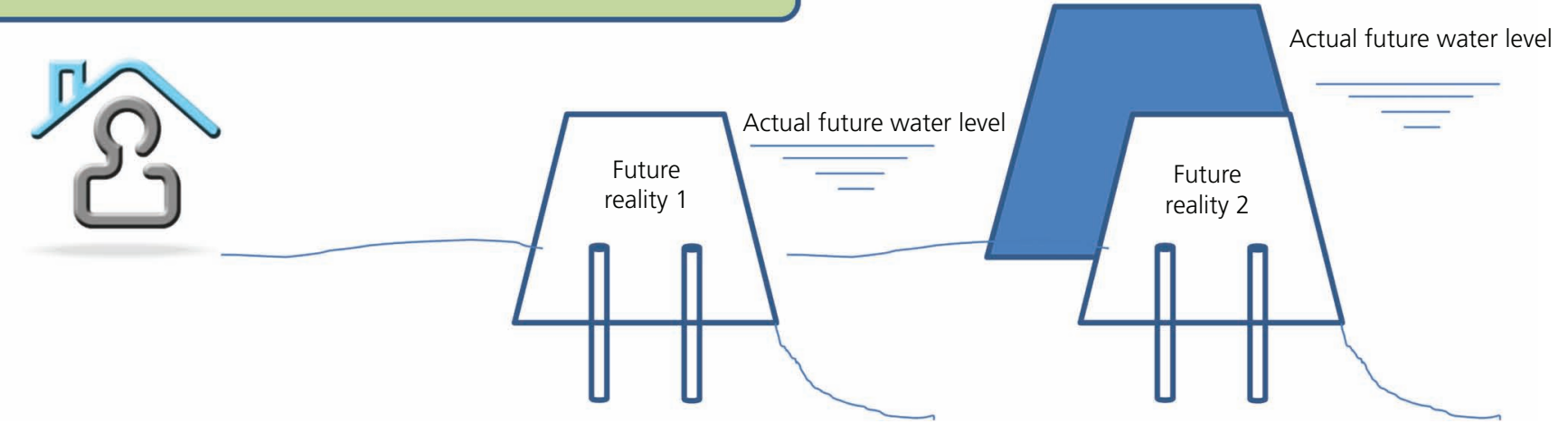

Figure 3. Adaptive design keeps future options open without incurring unnecessary additional expenditure (source: Sayers et al., 2012b).

footprint of the physical floodwaters. Understanding the spatial cascade of impacts through infrastructure networks (Brown and Dawson, 2013) and the economy (Crawford-Brown et al., 2013), and the measures implemented to manage these risks, should be considered to make a legitimate contribution to FCERMi.

Property owners can act to increase the demand they place upon system-scale infrastructure or reduce it (Defra, 2012). For example, by improving their resilience to future changes in climate (by installing property-scale resilience measures or making provision to protect the owner business functions from flooding or erosion risks), they can also impact positively on the infrastructure upon which they depend. A review by the ASC (2011a) highlights that there is limited evidence of the uptake of adaptation measures in the retrofit or repair of existing properties, despite a number of reasonably low-cost measures for existing buildings. Householders and developers require the right incentives to take action. The ASC's second progress report found instances where there is either a lack of or misaligned incentives, both of which lead to an inefficient adaptation outcome. Levers other than regulation, such as insurance incentives and better information, may be more important for existing homes (ASC, 2011b).

\section{Alternative approaches to managing flood risk}

New approaches to the design and construction of flood defences are seeking to provide multiple uses and benefits (Anvarifar et 
al., 2013; Kundzewicz, 1999). Crucial to FCERMi is the role of soft infrastructure, such as green spaces in urban areas, wetlands, channels, beaches and mudflats. Such features provide a wide range of benefits, including habitat creation and aesthetic value. These systems make important contributions to the management of flood and erosion risks (e.g. Sayers et al., 2015). Uncertainties associated with their performance have, in part, been responsible for hindering their uptake as it is difficult to reliably compare them against more traditional engineered infrastructure. This will need to change if we are to maximise the multiple benefits and inherent adaptability such systems provide.

Similarly, there are a wide range of propositions for redesigning houses and towns (Casey, 2012) from raising houses onto stilts through to floating artificial island communities. These measures all intend to help society 'live with water'. Pervasive sensors and the move towards real-time monitoring of condition and loads could provide a significant contribution to more targeted maintenance and emergency response (Pengel et al., 2013). Ultimately, this might help promote the update of adaptive management and lead away from a bias towards design conservatism and precautionary allowances that can lead to maladaptations.

\section{Conclusions: towards adaptive infrastructure}

Decisions concerning the planning, design and management of FCERMi are often long lasting and may be costly to reverse. This review has highlighted that, with a high degree of confidence, climate change can be expected to

- Impact the performance of FCERMi in a number of ways: $(i)$ reduce the standard of protection provided by existing assets: the nominal standard of protection afforded by the asset is likely to decrease as linear structures (e.g. embankments) are more frequently overtopped and in-line structures are bypassed as flow rates exceed the capacity of the pump or culvert); (ii) degrade structure reliability: as the rate of deterioration increases in response to more frequent or more severe storm loads (or both), changes in temperature give rise to more aggressive microbiological attack and dieback of vegetation on green infrastructure that is intolerant to a changed envelope of climatic conditions; (iii) reduce the maintenance window: due to an increased frequency of on-demand use, a lack of downtime for maintenance may lead to an increase in on-demand failure (e.g. mechanical and electrical assets such as the Thames Barriers, pumps and gates).

- Increase costs due to both greater capital investment and a need for enhanced maintenance including: $(i)$ increased recycling and recharge; (ii) more frequent on-demand use and associated maintenance costs; (iii) more vigorous vegetation growth (including invasive species); (iv) management of surface covers including grass and concrete; $(v)$ new build costs: where appropriate sea level rise and changing rainfall/ flows will demand new/improved defences; and ( $v i)$ the purchasing of future adaptive capacity (through, for example, strengthening foundations, land banking, designing for multifunctional use).

The review has also highlighted that the need to transform our approach to incorporating climate change, and the associated severe uncertainties in terms of the specifics of the future change, into planning and design choices remains a significant challenge. Meeting this challenge will require advances in research, policy and practice. The three top priorities in this area are

- Research to improve understanding of infrastructure response to weather and climate change. Above all, this review has highlighted that while it is well known that climate change can influence the performance of FCERMi in a number of ways, our understanding of the reliability of the infrastructure, the physical processes of time-dependent deterioration and the impact of changing loads (and the interactions between these) is extremely poor. A significant research effort is needed to advance this understanding and encourage the development of innovations in infrastructure design and management. There is huge potential to exploit new techniques for capturing and analysing, in real-time or otherwise, data from sensors, remote sensing, social media and other observations on the performance and condition of FCERMi. To fully exploit this new understanding of infrastructure performance will require better understanding of the projected changes in extreme values, but also more subtle climate characteristics such as spatial coherence and temporal sequencing and, crucially, how these changes are mediated by hydrological and coastal processes.

- Changes in practice that promote flexible planning and design. The FCERMi sector has been at the forefront of identifying possible climate impacts (through studies such as the LongTerm Investment Strategy (Environment Agency, 2009, 2014) and the UK Climate Change Risk Assessment (Defra, 2012)). However, ASC (2010) noted that 'despite good progress in building capacity and raising awareness, little has changed "on the ground" '. In part, the limited adoption of more adaptive strategies within the FCERMi industry is associated with difficulties in visualising exactly what these are, how they might operate, and how they combine cultural and environmental values with economic and flood management benefits. Development of new understanding and alternative business models to fund and finance FCERMi must run in parallel to mainstream an understanding of adaptive options, with examples, to encourage innovative and development of FCERMi that is appropriately resilient to future change, capable of modification, and delivers multiple benefits.

- Changes in appraisal process that encourage cost-effective strategies that take account of future uncertainties. The principles of making robust choices in the face of future uncertainty have matured within academic literature (e.g. Sayers et al., 2012b), and through the AdCAP (Adaptative Capacity) programme, these lessons are starting to be translated into practical guidance. However, new systems 
analysis tools will be required if assessment is to move beyond general statements (e.g. the relationship between sea level rise and increased wave heights, etc.) towards quantified analysis of long-term strategies of portfolios of FCERMi measures that are robust and flexible to a wider range of possible future changes (e.g. climate loadings, socioeconomic changes). Identification of possible tipping points, which may limit effectiveness of strategies beyond certain amounts of change, will be crucial to this. However, the vocabulary to describe a tipping point in, for example, the changes to spatial coherence or temporal sequencing, yet exists. Social and organisational systems could be put in place to minimise the impact of events that exceed the capacity of FCERMi; this can be supported by inherent designing for 'graceful failure' (Tye et al., 2014).

\section{Acknowledgements}

This work is based upon a working paper originally commissioned by the Living With Environment Change programme (www.lwec. org.uk) - Sayers and Dawson (2014). The authors would like to acknowledge the reviewers of that work, including Jon Blanksby (University of Sheffield), Keith Colquhoun (Thames Water), Roy Richardson (SEPA), Raghay Pant (University of Oxford), Jonathan Simm (HR Wallingford) and Owen Tarrant (Environment Agency). The authors would also like to thank the two anonymous reviewers for their comments and suggestions that have helped improve this manuscript. This work is part funded through the Research Centre iBUILD: Infrastructure BUsiness models, valuation and Innovation for Local Delivery (EP/K012398/1). Paul Sayers is part funded under the NERC FoRUM grant (NE/M008851/1) led by the Environmental Change Institute, University of Oxford. Richard Dawson is funded by an EPSRC fellowship (EP/H003630/1).

\section{REFERENCES}

Anvarifar F, Zevenbergen C and Thissen W (2013) An exploration of multifunctional flood defences with an emphasis on flexibility. International Conference on Flood Resilience Experiences in Asia and Europe, 5-7 September, Exeter, UK.

Armitage N, Vice M, Fisher-Jeffes L et al. (2012) Sustainable Drainage Systems - Report and South African Case Studies. Water Research Commission Report Number 1826/1/13, Water Research Commission, South Africa.

ASC (Adaptation Sub-Committee) (2010) How Well Prepared is the UK for Climate Change? Defra, London, UK.

ASC (2011a) Adapting to Climate Change in the UK-Measuring Progress. Defra, London, UK.

ASC (2011b) How Well is Scotland Adapting to Climate Change? Defra, London, UK.

Atkins (2006) Thames Estuary 2100 IA5 - 7 Active Structures Reliability Assessment. Environment Agency, Bristol, UK.

Auld $\mathrm{H}$, Klaassen J and Comer N (2007) Weathering of Building Infrastructure and the Changing Climate: Adaptation Options. Adaptation and Impacts Research Division, Environment Canada, Occasion Paper 11, Canada.
Blenkinsop S and Fowler HJ (2007) Changes in drought frequency, severity and duration for the British Isles projected by the PRUDENCE regional climate models. Journal of Hydrology 342(1-2): 50-71.

Brown S and Dawson RJ (2013) Disruption of resource movements from flooding. International Conference on Flood Resilience Experiences in Asia and Europe, 5-7 September, Exeter, UK.

Buijs FA, Hall JW, Sayers PB and Van Gelder P (2009) Timedependent reliability analysis of flood defences. Reliability Engineering and System Safety 94(12): 1942-1953.

Burgess K and Townend I (2004) The impact of climate change upon coastal defence structures. Defra Flood and Coastal Management Conference, 29 June-1 July, York, UK.

Burke EJ, Perry RJH and Brown SJ (2010) An extreme value analysis of UK drought and projections of change in the future. Journal of Hydrology 388(1): 131-143.

Cardoso AH and Bettess R (1999) Effects of time and channel geometry on scour at bridge abutments. Journal of Hydraulic Engineering 125(4): 388-399.

Casey A (2012) Does the threat of climate change and sea level rise present a unique opportunity to re-imagine the way we live with water? Journal of the Department of Planning and Architecture 4: 99-101.

Chini N, Stansby P, Walkden M et al. (2011) Modelling long term implication of climate change projection on shore morphology of north Norfolk, UK, combining TOMAWAC and SCAPE. Coastal Engineering Proceedings 32.

Chun KP, Wheater H and Onof C (2013) Prediction of the impact of climate change on drought: an evaluation of six UK catchments using two stochastic approaches. Hydrological Processes 27(11): 1600-1614.

CIRIA (2005) Management of Accelerated Low Water Corrosion. CIRIA C364, London, UK.

Crawford-Brown D, Syddall M, Guan D et al. (2013) Vulnerability of London's economy to climate change: sensitivity to production loss. Journal of Environmental Protection 4(6): 548-563.

Dawson RJ and Hall JW (2006) Adaptive importance sampling for risk analysis of complex infrastructure systems. Proceedings of the Royal Society A 462(2075): 3343-3362.

Dawson RJ, Dickson ME, Nicholls RJ et al. (2009) Integrated analysis of risks of coastal flooding and cliff erosion under scenarios of long term change. Climatic Change 95(1-2): 249-288.

Defra (2012) The UK Climate Change Risk Assessment 2012: Evidence Report. Defra, London, UK.

Defra (2013) Japanese Knotweed, Giant Hogweed and Other Invasive Plants. Defra, London, UK. See https://www.gov.uk/ japanese-knotweed-giant-hogweed-and-other-invasive-plants (accessed 20/03/2014).

Demuzere M, Orru K, Heidrich O et al. (2014) Mitigating and adapting to climate change: multi-functional and multiscale assessment of green urban infrastructures. Journal of Environmental Management 146: 107-115.

Dunne T and Black RD (1970) Partial area contributions to storm water runoff in a small New England catchment. Water Resources Research 6(5): 1296-1311. 
Environment Agency (Undated). Adapting to Climate Change: Advice for Flood and Coastal Erosion Risk Management Authorities. Environment Agency, London, UK. See http:// a0768b4a8a31e106d8b0-50dc802554eb38a24458b98ff72d 550b.r19.cf3.rackcdn.com/geho0711btzu-e-e.pdf (accessed 20/03/2014).

Environment Agency (2008) EurOtop - Wave Overtopping of Sea Defences and Related Structure: Assessment Manual. Environment Agency Science Summary SC050059/SS. Environment Agency in collaboration with European Partners, Heide, Germany. See http://www.overtopping-manual.com/ eurotop.pdf (accessed 28/11/2014).

Environment Agency (2009) Long Term Investment Strategy. Environment Agency, Bristol, UK.

Environment Agency (2012) Toe Structures Management Manual. Environment Agency, Bristol, UK.

Environment Agency (2013) Assessment and Measurement of Asset Deterioration. Environment Agency, Bristol, UK.

Environment Agency (2014) Accounting for Adaptive Capacity in FCERM Options Appraisal. Environment Agency, Bristol, UK.

Evans EP, Ashley R, Hall JW et al. (2004a) Foresight Future Flooding, Scientific Summary: Volume 1: Future Risks and Their Drivers. Office of Science and Technology, London, UK.

Evans EP, Ashley R, Hall JW et al. (2004b) Foresight Future Flooding, Scientific Summary: Volume 2: Managing Future Risks. Office of Science and Technology, London, UK.

Foster SSD (2001) The interdependence of groundwater and urbanisation in rapidly developing cities. Urban Water 3(3): 185-192.

Glendinning S, Hall JW and Manning LJ (2009) Assetmanagement strategies for infrastructure embankments. Engineering Sustainability 162(2): 111-120.

Gu JD, Ford TE and Mitchell R (2011) Microbiological corrosion of concrete. In Uhlig's Corrosion Handbook, 3rd edn. (Winston Revie R (ed.)). John Wiley \& Sons, Hoboken, NJ, USA, pp. 451-460.

Hall JW, Sayers P, Walkden M and Panzeri M (2006) Impacts of climate change on coastal flood risk in England and Wales: 2030-2100. Philosophical Transactions of the Royal Society A: Mathematical, Physical and Engineering Sciences 364(1841): 1027-1049.

Hall JW, Dawson RJ and Wu X (2015) Analysing flood and erosion risks and coastal management strategies on the Norfolk coast. In Broad Scale Coastal Simulation (Nicholls RJ, Dawson RJ and Day S (eds)). Springer, New York, USA.

Harvey H, Manning LJ and Hall JW (2012) Adaptation strategies for the Thames Estuary in the context of accelerated sea level rise. In Comprehensive Flood Risk Management Research for Policy and Practice (Kljin F and Schweckendiek T (eds)). Taylor and Francis Group, London, UK, p. 235.

Hemer MA, Fan Y, Mori N, Semedo A and Wang XL (2013) Projected changes in wave climate from a multi-model ensemble. Nature Climate Change 3(5): 471-476.
Hinkel J, Nicholls RJ, Tol RS et al. (2013) A global analysis of erosion of sandy beaches and sea-level rise: an application of DIVA. Global and Planetary Change 111: 150-158.

Hiscock K, Sparkes R and Hodgson A (2011) Evaluation of future climate change impacts on European groundwater resources. In Climate Change Effects on Groundwater Resources, A Global Synthesis of Findings and Recommendations (Treidel H, Martin-Bordes JL and Gurdak JJ (eds)). UNESCO, International Hydrological Programme, Paris, France, pp. 351-366.

HM Government (2011) Climate Resilient Infrastructure: Preparing for a Changing Climate. The Stationery Office, London, UK.

HM Treasury (2011) The Green Book. Appraisal and Evaluation in Central Government. The Stationery Office, London, UK.

Holliday NP, Hughes SL, Dye S et al. (2010) Salinity. In MCCIP Annual Report Card 2010-11, MCCIP Science Review.

Horsburgh K and Lowe J (2010) Mean Sea Level and Sea Level Extremes. In MCCIP Annual Report Card 2010-11, MCCIP Science Review.

Iverson RM and Major JJ (1986) Groundwater seepage vectors and the potential for hillslope failure and debris flow mobilization. Water Resources Research 22(11): 1543-1548.

Karoly DJ and Stott PA (2006) Anthropogenic warming of central England temperature. Atmospheric Science Letters 7(4): 81-85.

Karunarathna H, Pender D, Ranasinghed O, Short A and Reeve D (2014) The effects of storm clustering on beach profile variability. Marine Geology 348: 103-112.

Kilsby CG, Jones PD, Burton A et al. (2007) A daily weather generator for use in climate change studies. Environmental Modelling \& Software 22(12): 1705-1719.

Kundzewicz ZW (1999) Flood protection - sustainability issues. Hydrological Sciences Journal 44(4): 559-571.

Lavery S and Donovan B (2005) Flood risk management in the Thames Estuary looking ahead 100 years. Philosophical Transactions of the Royal Society A 363(1831): 1455-1474.

Loveless J, Grant G and Karlsson R (1996) The effect of groundwater on scour at coastal structures. Proceedings of 25th Conference on Coastal Engineering, Orlando, FL, USA.

Macdonald D, Dixon A, Newell A and Hallaways A (2012) Groundwater flooding within an urbanised flood plain. Journal of Flood Risk Management 5(1): 68-80.

Melchers RE (2014) Long-term immersion corrosion of steels in seawaters with elevated nutrient concentration. Corrosion Science 81: 110-116.

Met Office and CEH (2014) The Recent Storms and Floods in the $U K$. Met Office, Exeter, UK.

Murphy JM, Sexton DMH, Jenkins GJ et al. (2009) UK Climate Projections Science Report: Climate Change Projections. Met Office Hadley Centre, Exeter, UK.

NAO (National Audit Office) (2014) Strategic Flood Risk Management. Report by the Comptroller and Auditor General. Defra, London, UK, 3 November.

Newson MD and Large ARG (2006) 'Natural' rivers, 'hydromorphological quality' and river restoration: a 
challenging new agenda for applied fluvial geomorphology.

Earth Processes and Landforms 31(13): 1606-1624.

Pengel B, Shirshov GS, Krzhizhanovskaya VV et al. (2013) Flood early warning system: sensors and internet. In Floods: From Risk to Opportunity (Chavoshian A and Takeuchi K (eds)). IAHS Red Book No. 357, CEH Wallingford, Oxfordshire, UK, pp. 445-453.

Pitt M (2007) Learning Lessons from the 2007 Floods. An independent review by Sir Michael Pitt. Cabinet Office, London, UK.

POST (2011) Natural Flood Management. POST Note 396, December 2011

Pullen T, Allsop W, Bruce T et al. (2007) Wave overtopping of sea defences and related structures: Assessment manual. See http://www.overtopping-manual.com (accessed 28/11/2014).

Rahiz M and New M (2013) 21st century drought scenarios for the UK. Water Resources Management 27(9): 1039-1061.

Ranasinghe R, Callaghan D and Stive MJ (2012) Estimating coastal recession due to sea level rise: beyond the Bruun rule. Climatic Change 110(3-4): 561-574.

Reeder T and Ranger N (2011) How Do You Adapt in an Uncertain World? Lessons from the Thames Estuary 2100 Project. World Resources Report, Washington, DC.

Rowan E, Evans C, Riley-Gilbert M et al. (2013) Assessing the sensitivity of transportation assets to extreme weather events and climate change. Journal of the Transportation Research Board 2326: 16-23.

Sayers P and Dawson RJ (2014) Climate impacts on flood and coastal erosion management infrastructure: supporting 'future ready' infrastructure. LWEC Infrastructure Report Card 2014. LWEC, London, UK.

Sayers PB, Wallis M, Simm JD, Baxter G and Andryszewski (2010) Towards the next generation of risk-based asset management tools. In Flood Risk Science and Management (Pender G, Thorne C, Cluckie I and Faulkner H (eds)). Blackwell Publishing Ltd, Chichester, UK.

Sayers P, Korternhaus A and Flickweert J (2012a) Supporting flood risk management through better infrastructure design and management. In Flood Risk: Planning, Design and Management of Flood Defence Infrastructure (Sayers PB (ed.)). Thomas Telford, London, UK, pp. 73-101.

Sayers PB, Galloway G and Hall JW (2012b) Robust decision making under uncertainty: towards adaptive and resilient flood risk management infrastructure. In Flood Risk: Planning, Design and Management of Flood Defence Infrastructure (Sayers PB (ed.)). Thomas Telford, London, UK, pp. 281-302.

Sayers PB, Galloway G, Penning-Rowsell E et al. (2015) Strategic flood management: ten 'golden rules' to guide a sound approach. International Journal of River Basin Management 13(2): 137-151.

Schmocker L and Hager WH (2013) Scale modeling of wooden debris accumulation at a debris rack. Journal of Hydraulic Engineering 139(8): 827-836.

Schweckendiek T, Vrouwenvelder ACWM and Calle EOF (2014) Updating piping reliability with field performance observations. Structural Safety 47: 13-23.
Sentenac P, Jones G, Zielinski M, and Tarantino A (2013) An approach for the geophysical assessment of fissuring of estuary and river flood embankments: validation against two case studies in England and Scotland. Environmental Earth Sciences 69(6): 1939-1949.

Soulsby RL, Sutherland J and Brampton AH (1999) Coastal Steepening, the UK view. HR Wallingford Report TR 91, HR Wallingford, Oxfordshire, UK.

Stewart MG, Wang $X$ and Nguyen MN (2011) Climate change impact and risks of concrete infrastructure deterioration. Engineering Structures 33(4): 1326-1337.

Streftaris G, Wallerstein NP, Gibson GJ and Arthur S (2012) Modeling probability of blockage at culvert trash screens using Bayesian approach. Journal of Hydraulic Engineering 139(7): 716-726.

Sturm TW, Ettema R and Melville BW (2011) Evaluation of BridgeScour Research: Abutment and Contraction Scour Processes and Prediction. National Cooperative Highway Research Program, Transportation Research Board of the National Academies, Washington, DC,USA.

Sutherland J and Gouldby B (2003) Vulnerability of coastal defences to climate change. Water and Maritime Engineering, ICE 156(WM2): 137-145.

Sutherland J and Wolf J (2002) Coastal Defence Vulnerability 2075. HR Wallingford Report SR 590, HR Wallingford, Oxfordshire, UK.

Sutherland J, Brampton AH, Obhrai C, Dunn S and Whitehouse RJS (2007) Understanding the Lowering of Beaches in Front of Coastal Defence Structures. Joint Defra/EA Flood and Coastal Erosion Risk Management R\&D Programme Stage 2 R\&D Technical Report FD1927/TR, Defra, London, UK.

Tarrant O and Sayers P (2012) Managing Flood Risk in the Thames Estuary: The Development of a Long Term Robust and Flexible Strategy. Thomas Telford, London, UK.

Taylor RG, Scanlon B, Döll P et al. (2013) Ground water and climate change. Nature Climate Change 3(4): 322-329.

Tham Y, Muneer T, Levermore GJ and Chow D (2011) An examination of UKCIP02 and UKCP09 solar radiation data sets for the UK climate related to their use in building design. Building Services Engineering Research and Technology 32(3): 207-228.

Turley C, Brownlee C, Findlay HS et al. (2010) Ocean acidification. In MCCIP Annual Report Card 2010-11, MCCIP Science Review.

Tye MR, Holland GJ and Done JM (2014) Rethinking failure: Time for a synergistic approach. Proceedings of Institute of Civil Engineering: Forensic Engineering in press.

UKMMAS (2010) Charting Progress 2: An Assessment of the State of UK Seas. Defra, London, UK.

van Gelder P, Buijs F, Van CM et al. (2008) Reliability Analysis of Flood Sea Defence Structures and Systems. FloodSite Report T07-0, HR Wallingford, Oxfordshire, UK.

Vidal JP and Wade S (2009) A multi-model assessment of future climatological droughts in the United Kingdom. International Journal of Climatology 29(14): 2056-2071. 
Walkden MJA and Hall JW (2005) A predictive mesoscale model of the erosion and profile development of soft rock shores. Coast Engineering 52(6): 535-563.

Wallerstein NP and Arthur S (2013) Culvert design and operation guide supplementary technical note on understanding blockage risks CIRIA. C720. CIRIA, London, UK.

Whal T, Haigh ID, Woodworth PL et al. (2013) Observed mean sea level changes around the North Sea coastline from 1800 to present. Earth-Science Reviews 124: 51-67.

Wilby R (2012) Future Flood Flows: Report Card. LWEC, London, UK.
Wols BA and van Thienen P (2014) Modelling the effect of climate change induced soil settling on drinking water distribution pipes. Computers and Geotechnics 55: 240-247.

Woodward M, Kapelan Z and Gouldby B (2013) Adaptive flood risk management under climate change uncertainty using real options and optimisation. Journal of Risk Analysis 34(1): 75-92.

Woolf D and Wolf J (2010) Storms and waves. In MCCIP Annual Report Card 2010-11, MCCIP Science Review, Lowestoft, Suffolk, UK.

\section{WHAT DO YOU THINK?}

To discuss this paper, please submit up to 500 words to the editor at journals@ice.org.uk. Your contribution will be forwarded to the author(s) for a reply and, if considered appropriate by the editorial panel, will be published as a discussion in a future issue of the journal. 